\title{
The Role of Faith Systems and Religions in the Future of Sustainable Development: An Islamic Outlook
}

\author{
Mamdouh M. A. Sobaihi ${ }^{1}$ \\ ${ }^{1}$ Department of Landscape Architecture, Faculty of Environmental Design, King Abdulaziz University, Jeddah, \\ Saudi Arabia \\ Correspondence: Mamdouh M. A. Sobaihi, King Abdulaziz University, Jeddah 21589, Saudi Arabia. Tel: \\ 966-5-0566-6332. E-mail:msubehi@kau.edu.sa
}

Received: July 14, 2019

doi:10.5539/jsd.v12n5p23
Accepted: August 24, 2019 Online Published: September 29, 2019

URL: https://doi.org/10.5539/jsd.v12n5p23

\begin{abstract}
Reference material concerning sustainable development has increased dramatically over the last decades, with more and more countries, agencies and businesses following the sustainable development ideals and principles. However, one of the most basic of human institutions has not contributed, and perhaps not allowed to contribute, to the debate. Religion and faith systems have a great potential in influencing not only the definitions of sustainable development but also concepts of human sustainable practices to achieve sustainable development goals. The main obstacle to the fulfillment of this potential appears to be the lack of outreach and acceptance of the scientific community to the religious and faith system institutions and individuals. In this paper, a review of the literature is carried out to shed light on the root of this schism between science and belief systems. In addition, the paper will highlight how the majority of the literature deals with process rather than the individual human being and how to make him/her a better practitioner of sustainability. It is also aimed that the paper shed some light on how religious and faith system ideals can be incorporated into sustainable development plans and systems. The main focus of the paper is to cast light on the religion of Islam and some of the Islamic teachings and Ideals and how they can be incorporated in delivering the message of sustainable development since the religion of Islam is forecast to be the largest faith on the planet in the not too distant future. In conclusion, a discussion on how the various religious networks can deliver the message of sustainability will be discussed.
\end{abstract}

Keywords: sustainable development, religion, Islam

\section{Introduction}

Over the last forty years, the literature concerning sustainable development and/or sustainability has grown in an astonishing rate covering areas of knowledge such as engineering, planning, design, sociology, economy, anthropology, ecology and many more. Each area of knowledge contributes to the pursuit of the ideal of sustainability in no small measure and organizations leading the quest such as the United Nations (UN) are trying to organize and coordinate efforts between the private and public sectors, academia and non profit organizations to achieve sustainable development goals and objectives outlined by the scientific community, lawmakers, politicians and the public at large. The urgencies to fulfill goals and objectives to curb the ill effects of human activities on the environment are being highlighted continuously by the findings and facts of scientific research on a daily basis. Thus a coordinated and willful effort is required by all of the institutions of mankind to reach a sustainable method of development and equilibrium with nature.

Perhaps one of the most powerful if not the most powerful of all human cultural institutions has not had as much input as others in the sustainability debate namely that of religion. While there are a few articles and writings scattered throughout the literature concerning religion and the role it has to play in the promotion of sustainability ideals and thoughts, in comparison to the many roles religions play throughout the world in promoting ideologies, thoughts and especially attitudes the efforts leave a lot to be desired. It is thus the purpose of this paper to examine the roles religion have played in the past and can play in promoting concepts and ideas of sustainability through a review of the literature. It is also the purpose of this paper to examine in some detail the role of Islam in promoting sustainability and sustainable development ideals and concepts in Muslim countries. This becomes more critical when one examines demographic and economic facts. One of these facts is that the large global Muslim population (approx. 1.8 billion in 2015), (Lipka \& Hackett, 2017). Another fact is 
the continual growth of Islam as a religion throughout the world to reach an estimated 3 billion by 2060 (Lipka \& Hackett, 2017), which would render it the largest faith on the planet. Furthermore, economically developing countries have a sizeable Muslim population (See Table 1). In addition, there is the unfortunate fact that some of the worst polluters per. Capita in the world are Muslim countries (See Table 2).

Table 1. Percentage of population that is Muslim in fastest developing economies of the world. FocusEconomics (2019) \& Wikipedia (2019a)

\begin{tabular}{lll}
\hline Rank & Country & \%age of Population That is Muslim \\
\hline 1 & Ethiopia & $34 \%$ \\
2 & Rwanda & $4.8 \%$ \\
3 & Bangladesh & $90.4 \%$ \\
4 & India & $14.2 \%$ \\
5 & Cote d'Ivoire & $42.9 \%$ \\
6 & Cambodia & $1.9 \%$ \\
7 & Myanmar & $4.3 \%$ \\
8 & Laos & $<0.1 \%$ \\
9 & Vietnam & $0.1 \%$ \\
10 & Tanzania & $35.2 \%$ \\
11 & Philippines & $5-11 \%$ \\
12 & Senegal & $96 \%$ \\
13 & China & $0.45-3 \%$ \\
14 & Mongolia & $5 \%$ \\
15 & Ghana & $18 \%$ \\
\hline
\end{tabular}

Table 2. Percentage of population that is muslim in countries of highest $\mathrm{CO}_{2}$ emissions/capita. Wikipedia (2019a) \& Wikipedia (2019b)

\begin{tabular}{lll}
\hline Rank & Country & \%age of Population That is Muslim \\
\hline 1 & Palau & $<0.1 \%$ \\
2 & Qatar & $77.5 \%$ \\
3 & Trinidad \& Tobago & $5.8 \%$ \\
4 & Bahrain & $73.7 \%$ \\
5 & Kuwait & $74.6 \%$ \\
6 & United Arab Emirates & $76 \%$ \\
7 & New Caledonia & $2.8 \%$ \\
8 & Saudi Arabia & $97.1 \%$ \\
9 & Gibraltar & $4 \%$ \\
10 & Canada & $3.2 \%$ \\
11 & Oman & $85.9 \%$ \\
12 & Australia & $2.6 \%$ \\
13 & Luxembourg & $3 \%$ \\
14 & United States & $1.1 \%$ \\
15 & Brunei & $78.8 \%$ \\
\hline
\end{tabular}

Thus the focus of this paper is on Islamic principles that can be incorporated in the sustainable development 
debate. Although these principles may carry the Islamic tag, nonetheless these principles may apply to any belief or faith that subscribes to the proposition that humans exist in a greater sphere than that which surrounds them physically in space and time and that mankind is part of a more complex environment that spans beyond the planet we live on and the time we live in.

\section{Definitions and Principles of Sustainable Development}

There is no one agreed upon definition of sustainable development and/or sustainability, however there seems to be a general agreement that the definition put forth by the 1987 World Commission on Environment and Development (commonly known as the Brundtland Commission) in their landmark document Our Common Future provides a good basis and encompasses the main principles of sustainable development. In the report sustainable development is defined as development which, "meets the needs of the present without jeopardizing the ability of future generations to meet their own needs". This definition highlights several important principles imperative to this paper and argument.

The first being that development will occur, the definition highlights this fact clearly and does not mean to hinder development. The stress is on how development should occur. Second, the definition highlights the need to preserve resources and opportunity for developmental needs and beyond for future generations. As such development should incorporate the variable of time in all equations, prospects and feasibilities. The third point emphasized in the definition is "needs". Human "needs" is a very subjective and inconclusive issue and perhaps is one of the main issues upon which sustainable development and resource management falter. One person's "needs" is another person's luxury. Where the line is drawn and the purpose of establishing such needs and to what cultural and/or ethnic standard it is made; will be a very debatable subject now and for future generations to come. However, one certainty is beyond debate, that one of the main issues with development today and the necessity to adopt more sustainable methods in development is rooted in the fact that humans cannot curb the desire for more and more. When we see that the richest 200 individuals in the word have accumulated more than the lowest 2.5 billion people alarm bells should ring indicating something has fundamentally gone awry (Kamali, 2015). As Hasan (2006) states, "the world is likely to be overwhelmed by the development problems of the sort it is now facing if men do not resist selfishness, greed and rapacious exploitation of natural resources" (p.5).

Thus we may summarize the principles that are found in the widely accepted definition of sustainable development into three main points.

a) How development is to occur: Process.

b) By whom development should occur: Time.

c) How much development is to occur: Belief (satisfaction).

It is regrettable that most of the literature available on sustainable development is on the first highlighted point, process. Where the human elements of sustainable development such as belief and time (generational prosperity) have received much less attention. By so doing, progress towards curbing the ill effects of global warming, natural resource depletion and global environmental pollution has been slow and tiresome. Regulations, treaties and accords can achieve many things, but human history has shown us that humans excel when they believe and fully subscribe to an ideal or faith. Some would argue this fact is the cornerstone of human civilization and all its constructs. If so, then we must look at belief systems and faiths of people and how sustainable developments can be promoted through these faith systems and beliefs.

The alarming environmental degradation humanity is currently witnessing is due mostly to the human factors of greed, exploitation and domination. The ethical dimension is, therefore, fundamental to a comprehensive understanding of sustainable development. (Kamali, 2015;p.11)

\section{Role of Religion and Faith in Sustainable Development}

Concepts of the world, nature and indeed the universe at large, are formulated by people with a notable influence from their faith systems. The treatment of animals and nature can be found in most religions of the world. Furthermore, many faith systems identify the role of man in the greater scheme of life nature and beyond. As such, attitudes towards how the earth, resources and natural systems are to be treated and utilized are linked to faith systems throughout the world. Many agree that the potential of faith systems in promoting sustainability and sustainable development is great. As Hitzhusen \& Tucker (2013) put it,

The world's religious communities have much to offer because attitudes and belief that shape most people's concept of nature are greatly influenced by 
their religious worldviews and ethical practices. .... The moral imperatives and value systems of religions have the potential to mobilize the sensibilities of people toward the goals of earth stewardship. (p.368)

With such potential, one wonders why faith systems and religions have not had a much bigger role in promoting sustainable development topics and issues. The available literature has pointed out four main reasons for this lack of influence. First, there seems to be an allegation that Judeo-Christian faiths by placing man at the top of all creations suggests man being superior to other creatures.

“..... our Judeo-Christian religious philosophy that sharply separates man from nature and holds the former as having dominion over the latter; thus, human beings are viewed as entitled to use nature in a way that is most beneficial to our welfare, with little or no regard for other considerations." (Jepson, 2001; p.501)

As such, such attitude or belief has led to "practices that have led to the destruction of nature" (Parker, 2015;p.286) and are still the prevalent practices of development in western societies (Judeo-Christian societies) (Hitzhusen \& Tucker, 2013). Second, the adherence of faith systems and religions in the world has been declining steadily since the latter part of the nineteenth century especially in the developed world (Al-Rawahy, 2013). Third, religions and their preachers have failed to make the issues of climate change, energy consumption and/or sustainability and sustainable development part of their message to the faithful (Parker, 2015; Al-Rawahy, 2013). Fourth, is the general miscommunication and/or lack of communication between the scientific communities and the religious communities, where scientist believe the issues of sustainability are in the tangible world and that the world of faith has no place in it (Johnston, 2010; Hitzhusen \& Tucker, 2013).

It is therefore very evident that for such powerful institutions of human culture and society, religions and faith systems have had very little input in the sustainability and sustainable development struggle. The potential is great, however realizing that potential is still elusive and slight. In the next section, Islamic principles that maybe used in the sustainable development argument will be examined and put forth. These principles will form the basis from which the religion and its practitioners could be brought to the forefront of tackling sustainability and sustainable development issues. Furthermore, these principles could and should apply to other religions as indicated earlier, although the referencing and the examples used here are targeting Muslim populations and the Islamic faith.

\section{Islamic Principles Relating to Sustainable Development}

In 2012 The Islamic Declaration on Sustainable Development (IDSD) was published. The IDSD maintains that, "Islam's vision of economic development is entrenched in the ethical norms of Islam, which stress mankind's responsibility in the utilization, allocation and preservation of natural resources, considered as gifts from God to humanity". (Kamali, 2015;p.9)

While this declaration is the conclusion of thought and a formulation of a position, it does not identify the basis on which this position and conclusion is reached. Thus, for a better understanding and a more effective way of dissipating ideals of religion towards sustainable development the foundations on which the declaration was built need to be highlighted and revealed.

Reviewing the literature, contemplating the faith and referring to the teachings of the Quran and Sunnah (prophet Mohammed peace be upon him sayings and history), it becomes clear that there are mainly three principles that direct attitudes and actions related to the sustainable development debate. These three principles are, 1) the role of man on earth, 2) the way in which things are to be used and utilized and 3) the foundations and/or the roots from which Islamic law (Shariah) is formulated. A brief outline of each will be provided to clarify.

- The Role of Man on Earth:

According to Islam and Islamic teachings, the main purpose of man's placement on earth is to be God's vicegerent on earth.

Behold, thy Lord said to the angels: "I will create a vicegerent on earth"....... (The Holy Quran 2:30)

By being the vicegerent of the Lord on earth, man is supposed to rule by the laws provided by God. Furthermore, man is placed on earth to develop earth (Imar Al-Ardh) by stewardship and principles of custodianship where all creatures and environments have the right to prosper and thrive. Some would even argue that the Islamic principles expand beyond the bounds of earth (Kamali, 2015). Meaning humans were granted the role of 
vicegerent to oversee the development of all aspects of life with no harm to the environment and the understanding that man functions in harmony with all other creations of God. As Kamali (2015) put it, "humans are stewards and custodians of the earth, with a mission to build it .... and establish a just social order therein" (p.13). The principle of custodianship put forth here is further reinforced by prophet Mohammed (peace be upon him) in his saying, "There shall be no damage and no infliction of damage" (Abumoghli, 2016). Which offers the main guiding directive in life, development and relationships for Muslim philosophy. Many thinkers and scholars in time have expanded on this main definition of the role of man in scope and in breadth throughout Islamic history. One of the more interesting suggestions that relates to sustainability in this day and age is Ibn Khaldoon's $\left(14^{\text {th }}\right.$ century historian and scholar $)$ interpretation will require a deeper understanding and assessment of Imar Al-Adh , where systems and professions must follow the principles of custodianship and stewardship. He suggests that with the "transition from a nomadic lifestyle to the building of cities, attention to arts and sciences, industries and professions, as well as effective leadership roles that direct and control various stages of progress in civilization building" must take place and evolve (Ibn Khaldoon, 1377)

- Consumption, Utilization and Use:

How things are to be utilized, used and consumed lies at the heart of the problems of exploitation, environmental degradation and unsustainable development. Within Islam and Islamic principles, the directive to consume in moderation and to avoid excess of any form is highlighted and stressed vigorously (Dariah etal., 2015; Abumoghli, 2016). These directives span not only to produce and food, but also to water, dress and the environment as a whole. In the Quranic verses that stress mischief, perhaps the meaning is lost in the translation. In Arabic the word (Fassad) could mean one or all the meanings of mischief, ruin and destroy, or misuse at once.

But seek, with the (wealth) which Allah has bestowed on thee, the Home of the Hereafter, nor forget thy portion in this world: but do thou good, Allah has been good to thee, and seek not mischief in the land: for Allah loves not those who do mischief. (The Holy Quran, 28:77)

O Children of Adam! Wear your beautiful apparel at every time and place of prayer: eat and drink: but waste not by excess, for Allah loveth not the wasters. (The Holy Quran, 7:31)

And follow not the bidding of those who are extravagant, Who make mischief in the land and mend not. (The Holy Quran, 26:151-152)

It is He Who produceth gardens, with trellises and without, and dates, and tilth with produce of all kinds, and olives and pomegranates, similar (in kind) and different (in variety): eat of their fruit and season, but render the dues that are proper on the day that the harvest is gathered. But waste not by excess: for Allah loveth not the wasters. (The Holy Quran, 6:141)

Do not mischief on the earth, after it hath been set in order, but call on Him with fear and longing (in your hearts): for the Mercy of Allah is (always) near to those who do good. (The Holy Quran, 7:56)

It is thus very clear and evident that while the development of earth and the prosperity of people through the stewardship and custodianship of the planet and the environment at large, wastefulness, over consumption and excess of any manner is frowned upon by the teachings and principles of Islam.

- Islamic Law (Shariah)

Shariah or Islamic law is the guiding set of legislation that covers all aspects of a Muslim's life and practices. Shariah law is formulated by referring to the scriptures of the Quran, the Prophet's (peace be upon him) sayings and history as well as the accumulated knowledgeable of scholars, clergy and scientist as well as the continual research and contemplation within any given field.

O ye who believe! Obey Allah, and obey the Messenger, and those charged with authority among you. If ye differ in anything among yourselves, refer it to Allah and His Messenger, if ye do believe in Allah and the Last Day (of Judgment): That is best, and most suitable for final determination. (The Holy Quran, 4:59)

Thus Shariah can be seen as setting the boundaries of the paradigm of Imar Al-Ardh (development and life). Islamic law has detailed objectives that formulators of Shariah law cannot veer away from. These objectives subscribe to the principles that all laws should serve humanity and to safeguard the a) faith, b) self, c) intellect, d) posterity and e) wealth of all individuals according to the directives and purposes of God's creation (Hasan, 2006). It is thus surmised that Shariah law in Islam serves the development (Imar Al-Ardh) according to and in line with principles of moderation in consumptions and avoidance of excess. These laws should safeguard 
people's (of all faiths and beliefs) rights towards practicing their faiths while having opportunity to prosper themselves in an environment that can cater for the wellbeing of the individual both physically and mentally and grant the same opportunity for the future generations to come.

\section{Conclusions and Discussion}

As all other religions Islam is concerned with the salvation of human souls and rewarding of good deeds and having faith in the afterlife or in other forms of existence. Through these good deeds, practices and treatment of people, and in the case of Islam environments, humans become closer to God and/or arguably nature, the environment and the universe. In this paper an examination of definitions concerning sustainable development has shown that the existing definitions revolve around three axes, namely a) process, b) time (generational opportunity) and c) limits of development (concentrating on needs). The majority of attention that has been formulated in the discussions and the provisions of solutions for sustainable developments has been mainly focused upon the processes of development.

Very little in terms of tackling the underlying issues and problems of people's attitudes towards development, safeguarding resources for future generations and moderation in consumption and use has been made. Religions and faith systems, as illustrated in this paper, offer the opportunity to reach people and address these issues. While each religion and faith system may offer different solutions on linking people's beliefs in the religion to sustainable development, most faith systems will probably agree upon that sustainable development can be considered a good deed and as such would be easier to incorporate in the faith system's doctrine.

The example that was offered here by examining Islam as a faith system and identifying a) man's role in the universe and on earth, b) the manner in which development, use and consumption should take place and c) how the legislative construct can support and reinforce sustainable development ideals is but a first step on a long road.

Islam according to estimates will be the faith of most people on the plant not too distant in the future (Lipka, M. \& Hackett, C., 2017). Thus if we start applying some efforts in formulating plans to address the Muslim population, we would be assured that the (soon to be) largest faith and its teachings are in-line with ideals and concepts of sustainable development.

Throughout this paper, issues of sustainable development and the positive role religions and/or faith systems can have were illustrated. The potential for this impact is substantial, especially when one considers the vast networks of mosques, churches, synagogues, temples and places of worship and/or contemplation. These places of worship all have the latent possibility of being a place and a platform to deliver the message of sustainable development and address issues of over consumption, pollution and excess. The responsibility of spreading the message of sustainability and sustainable development goes beyond the scope and jurisdiction of one particular group or individuals. It is thus imperative that scientist, clergy, politicians, teachers and all sectors of the society interact and find a way to deliver and spread the message of sustainable development and quickly. The situation calls for all to act, and the long-standing disputes between science and faith must be resolved and disregarded to tackle the existential issues that face us and threaten us all.

\section{References}

Abumoghli, A. (2016). Islamic Principles on Sustainable Development. EcoMENA. Retrieved from www.ecomena.org/islam-sustainable-development/

Al-Rawahy, K. H. (2013). Engineering Education and Sustainable Development: The Missing Link, Elsevier: Procedia - Social and Behavioral Sciences 102 pp.392-401. $6^{\text {Th }}$ International Forum on Engineering Education (IFEE 2012). https://doi.org/10.1016/j.sbspro.2013.10.754

Dariah, A. R., Salleh, M. S., \& Shafiai, H. M. (2015). A New Approach for Sustainable Development Goals in Islamic Perspective. Elsevier: Procedia - Social and Behavioral Sciences 219 pp.159-166. $3^{\text {rd }}$ Global Conference on Business and Social Science. https://doi.org/10.1016/j.sbspro.2016.05.001

FocusEconomics. (2019). The World's Fastest Growing Economies. Retrieved May 7, 2019, from https://www.focus-economics.com/blog/fastest-growing-economies-in-the-world

Hasan, Z. (2006). Sustainable Development from an Islamic Perspective: Meaning, Implications, and Policy Concerns. Journal of King Abdulaziz University: Islamic Economy, 19(1), 3-18. https://doi.org/10.4197/islec.19-1.1

Hitzhusen, G. E., \& Tucker, M. E. (2013). The Potential of Religion for Earth Stewardship. Frontiers in Ecology and Environment, 11(7), 368-376. https://doi.org/10.1890/120322 
Huda. (2018). The World's Muslim Population. Retrieved May 7, 2019, from https://www.learnreligions.com/worlds-muslim-population-2004480

Ibn Khaldoon, A. M. (1377). Mugadimat Ibn Khaldoon \{The Magnum Opus\}. Beirut: Almaktaba Alassrya Printed (2006).

Jepson, E. Jr. (2001). Sustainability and Planning: Diverse Concepts and Close Associations. Journal of Planning Literature, 15(4), 499-510. https://doi.org/10.1177/088541220101500401

Johnston, L. (2010). The Religious Dimensions of Sustainability: Institutional Religion, Civil Society, and International Politics since the Turn of The Twentieth Century. Religion Compass, 4(3), 176-189. https://doi.org/10.1111/j.1749-8171.2009.00202.x

Kamali, M. H. (2015) Islam and Sustainable Development. IAIS Bulletin No.27, July-August 2015. Retrieved from www.iais.org.my

Lipka, M., \& Hackett, C. (2017). Why Muslims are The World's Fastest-Growing Religious Group. Retrieved May 8, 2019, from https:/www.pewresearch.org/fact-tank/2017/04/06/why-muslims-are-the-worlds-fastest-growing-religiousgroup/

Parker, C. G. (2015). Climate Change, Energy Transition and Religions. Social Compass, 62(3), $283-295$. https://doi.org/10.1177/0037768615587805

Sidibe, M. (2016). Religion and Sustainable Development. The Review of Faith \& International Affairs, 14(3), 1-4. https://doi.org/10.1080/15570274.2016.1215848

The Holy Quran. (Yusuf Ali Translation)

Wikipedia. (2019a). Islam by Country. Retrieved May 1, 2019, from https://en.wikipedia.org/wiki/Islam_by_country

Wikipedia. (2019b). List of Countries by Carbon Dioxide Emissions. Retrieved May 1, 2019, from https://en.wikipedia.org/wiki/List_of_countries_by_carbon_dioxide_emissions

World Commission on Environment and Development. (1987). Our Common Future. New York: Norton.

\section{Copyrights}

Copyright for this article is retained by the author(s), with first publication rights granted to the journal.

This is an open-access article distributed under the terms and conditions of the Creative Commons Attribution license (http://creativecommons.org/licenses/by/4.0/). 